\title{
THE EFFECTIVENESS OF DIGITAL STORYTELLING ON STUDENTS' SPEAKING ABILITY
}

\author{
Andi Idayani \\ Universitas Islam Riau \\ E-mail: andiidayani@edu.uir.ac.id
}

\begin{abstract}
Speaking is an assential skill that used be mastered by the Students, because it is necessary for them to improve their ability to communicate orally by presenting their ideas and opinions in real life. Digital storytelling is the practice of using computer-based tools to tell stories. It can be used as homework, classroom group projects, or a holiday project for students. In relation to this, the purpose of the research is to find out is there any significant effect of digital storytelling on students' speaking ability. Then, Describing and analyzing the effectiveness of digital storytelling in enhancing students' speaking ability. in this study, the researcher used experimental research. An experimental usually involves two groups of subject, an experimental group and a control group. The population of this research was the fifth semester of English students of FKIP - Islamic University of Riau in academic year 2018/2019. The sampling technique used in this research is purposive sampling. The researcher choose 5B as experimental class which consist of 26 students and $5 \mathrm{C}$ as control class which consist of 25 students. The reseracher used speaking test as instrument which included in pre-test and post-test. The results of the research revealed that $t_{\text {test }}>t_{\text {table }}(14,402>2.05954), t_{\text {table }}$ on degree freedom (df) 25 on the level of significant 0.05. Consequently, it means that the alternative hypothesis is accepted while the null hypothesis is rejected. So, the conclusion of the research has shown that there is positive effect of digital storytelling towards students' speaking ability.
\end{abstract}

Keywords: Speaking ability, digital storytelling, experimental research

\section{EFEKTIVITAS PENGGUNAAN DIGITAL STORYTELLING TERHADAP KEMAMPUAN BERBICARA SISWA}

\begin{abstract}
Abstrak
Berbicara adalah salah satu keterampilan penting yang harus dikuasai oleh mahasiswa, karena itu mereka perlu meningkatkan kemampuan berkomunikasi secara lisan dengan mengungkapkan ide-ide dan pendapat mereka dalam kehidupan nyata. Digital storytelling adalah praktik dengan menggunakan komputer untuk menceritakan kisah. Ini dapat digunakan sebagai pekerjaan rumah, tugas kelompok, atau tugas liburan untuk siswa. Sehubungan dengan ini, tujuan penelitian ini adalah untuk mengetahui apakah ada pengaruh Digital storytelling terhadap kemampuan berbicara siswa. Kemudian, menjelaskan dan menganalisa efektivitas penggunaan Digital storytelling dalam meningkatkan kemampuan berbicara siswa. Peneliti menggunakan penelitian eksperimental. Eksperimen biasanya melibatkan dua kelompok subjek, kelompok eksperimen dan kelompok kontrol. Populasi dari penelitian ini adalah semester lima mahasiswa Bahasa Inggris FKIP Universitas Islam Riau pada tahun akademik 2018/2019. Teknik pengambilan sampel yang digunakan dalam penelitian ini adalah purposive sampling. Peneliti memilih 5B sebagai kelas eksperimen yang terdiri dari 26 siswa dan 5 C sebagai kelas kontrol yang terdiri dari 25 siswa. Peneliti menggunakan tes berbicara sebagai instrumen yang termasuk dalam pre-test dan post-test. Hasil penelitian
\end{abstract}


mengungkapkan bahwa t-uji> t-tabel (14,402> 2,05954), t-tabel pada derajat kebebasan (df) 25 pada tingkat signifikan 0,05. Jadi, kesimpulan dari penelitian telah menunjukkan bahwa ada efek positif dari Digital storytelling terhadap kemampuan berbicara siswa.

Kata Kunci: Kemampuan berbicara, digital storytelling, penelitian eksperimen

\section{INTRODUCTION}

In higher education, speaking is a crucial skill that should be comprehend by the English Students, because it is neccesary for them to improve their ability to communicate orally in the future. Whereas, Speaking is characterize as an collective process of building up meaning that involves producing, receiving and processing information. This process and meaning are dependent on the context which it occurs, setting, participants, and the aims of speaking. From those statements above, the researcher can conclude that speaking is an activity involving some participants, speaker and listener, which discuss a topic related with context of situation.

English teachers might think that teaching speaking as laborious skill to teach, there are some reason about it; firstly, the limit opportunities and time consuming to practice speaking in the classroom. Secondly is students do not speak by using English but using their traditional language or bahasa Indonesia. Thirdly is some of them are afraid of doing mistakes when they speak with their friends. Futhermore, this situations did not help students to raise their speaking ability, consequently they become passive students in the classroom.

The role of technology cannot be neglected in English classroom. Teachers need online resources to construct the material for teaching. By using technology both teaching and learning process become interesting and meaningful. If both teachers and students have access to internet, there is some of audiovisual materials available online that could be used in English classroom. Stories are performed regularly and they learn how to tell stories in a variety of ways at numerous levels of education. Furthermore, storytelling is a decisive part of curriculum at schools.

Storytelling is observed as a comprehensive material because speakers use their grammatical and background knowledge to construct a message that will be meaningful to the proposed listeners in social context. However, speakers stimulate relevant schemata from definite context in order to transmit meaning for a specific aim with an intended listeners in their mind. Storytelling helps; (a) speakers to be able to understand meaning that is tranfered at a level before that of sentence, (b) speakers to have a goal which is to facilitate some informations, (c) speakers to have the valuable of what to say and how to say it, (d) speakers to have an objective in their mind while communicating (e) speakers to show some factors at the same times.

On the other hand, according to Karakoyun (2014) he said that digital storytelling is allowed students become active learners, created group communities with others, enhanced students to collaboration with their tim by using technology. This situation will be engaged with the goals of content inside or outside classroom circumtances.

According to Wang and Zhan (2010) digital stories are short videos designed by collaborating images, videos, musics and audibles or written narrations by some basic hardwares and softwares. Digital stories tools such as adobe slate, puppet pals, sock puppets, wevideo, inshot, hands starter with authentics stories. However, digital storytelling is not only a power point presentation but also vivid stories (Dreon, Kerper, and 
Landis, 2011). Therefore, digital story become comprehensive activities in classroom and in various subjects of study as mentioned by many teachers, researchers and experts. Related with statement above, the researcher was interested in conducting a research which was focused on the effectiveness of digital storyteling on students' speaking ability.

The aim of the study is to find out is there any significant effect of digital storytelling on students' speaking ability. Then, Describing, analyzing and explaining the effect of digital storytelling in enhancing students' speaking ability. Furthermore, it aims to increase teachers' awareness about the positive use of digital storytelling to motivate students and increase their speaking performance.

The significance of this research can be categorized from both theoretical and practical views:

1. Theoretically, this study is expected that it can be used as insistence to determine a digital media to increase the students' speaking ability after learning digital storytelling.

2. Practically, this research is expected to give other point of view to teachers currently for English teachers in teaching speaking skill. Based on this research, teachers may choose various kind of storytelling from stoytelling websites. In addition, this research can also give contribution to government regarding the technology that is obviously rarely conducted for teachers.

\section{Literature Review}

Speaking ability is the process of sharing and creating meaning by verbal and nonverbal codes. It is developed start from child life which is preceded by listening skill, because on that period the process of speaking is learned. It means that speaking skill is in the basic one that sholud be learned. According to Khorashadyzadeh (2014) said that in speaking, we not only needs learners' comprehending about the way to deliver their competence in linguistics like vocabulary, grammar, pronunciation but also understanding about sociolinguistic competences like how, when, why to speak.

Therefore, speaking is complex skill because when we communicate to others, we need to catch a special end which can be expressing our ideas, wishes, solving and negotiating problems or establishing and maintaining social relationships and friendships.

The main goal in learning English is to able to communicate well so they can use it in interaction. Therefore, it also found in daily communication while acquiring second language. Otherwise, speakers learn how to speak and deliver the massage that they are proposing and understanding. In this respect, speaking makes a major element in the performance of any verbal interaction since the production of words, phrases, and utterance would logically convey meanings, views, and intentions. In particular, speaking, in a foreign language, is deemed to be a central skill that EFL teachers and learners seek to develop. In parallel, speaking in the English language is a vital skill that benefits the speaker in and outside the classroom because of being as a linguafranca adopted in international affairs. In short, speaking, one of the language skills is responsible for the speech production. In this sense, it has been over emphasized as a central ability that promotes the overall success of communication among interlocutors.

Speaking ability is the students' capability in conveying their opinions by verbal or nonverbal symbols which is expressed by speaking scores. Then, speaking also as a tool that can use to communicate naturally between people as a social behavior form. Nowadays, in the world require that the purpose of teaching speaking is to develop students' 
communicative skills. Students could express their point of view and learn how to use language in various contexts. Finally, speaking may integrate with other language skills. Speaking ability also can support of conversation one person with other people in order to understand in many situations. Therefore we need some media to support the students' speaking ability.

\section{Technology and Media in Teaching English}

In education, the development of technology has brought beneficial to students and teachers. Such as students can do their task or project faster because of they use internet. Then, teachers also get some neccesary like: they might collaborate their teaching strategy with technology and produce some extraordinary materials to teach like flashy slides with audio to deliver the lesson and animation video to show how it happens. In addition, technology has given them advantages to develop their teaching materials for teachers and enlarge materials in studying for students.

Media in teaching improves the importance of interaction between students and teachers. For instance, it enhances the ability of students to listen and speak, and to increase their communication ability. Using media and technology in teaching makes a good exchange between the teacher and their students. Moreover, Madhavaiah et al. (2013) stated that the process of multimedia can be set of both teachers and students. Media can also enhance lessons by capturing students' attention and providing visual or auditory material in classroom.

According to Maggioli (2009), said that the technology admits students to differ the time they spend, the help they offer, and allows the passage they take towards a learning process. As well, it facilitate the teacher to give specific instruction to individual student.

On the whole, the main reasons of using media with technology in the process of teaching is to build up the students motivation and learning interest in English. Cherry (2017) also said that technology as a good tool for use in ourside and inside classroom such as digital storytelling. It combines the written text with visual image, audio, and creating stories.

Audiovisual aids as educational and training materials directed at both the sensitivity of hearing and the sensitivity of sight. In classroom instructions, teachers might use films, recording, photographs, and library collections in teaching (Webster's Encyclopeadia Unabridged Dictionary of the English Language, cited in Ashaver and Igyuve (2013). Then, they also states that the human being studies more faster and easily by audiovisual display rather than by verbal description only.

\section{The Use of Digital Storytelling}

Hartsell (2017) said that nowadays, it is not a new concept of digital storytelling in class. Because novelty of this activity has raised popularity with the divergence of different media and technology which can use to storytellers. They can access to digital and Web-based technology devices, then the art of digital storytelling has arrested shape and is used by teachers and students who like a form of innovative way of communication. Additionally, digital stories are designed by one or more storyteller, after that the final project incorporate creativity and self-expression in recounting events, people, concepts, and more.

Digital Storytelling in the classroom is about using technology to tell a story. It is similar to traditional storytelling, but in this case, we use computers or phone mobile to complement and add to the storytelling experience by using a variety 
of tools and aids like Microsoft Word, blogs and other websites. It motivates the students, in this case, to be creative and innovative in using several kinds of media for example video, images, and audio.

In general, digital storytelling, like traditional storytelling, focuses on the improvement of a chosen setting, theme or picture for the story. Therefore, the procedure of making story, students need to brainstorm the story, conduct small research, write script of story, and manage other componets which are interested for story. To transfering from storytelling to digital storytelling, there is one key difference between them such as digital storytelling is supported by a kind of digital multimedia tools. Digital storytelling combines a mixture of image, text, recorded audio from narrator, video and background of music to perform message on a specific ideas through technology (O’Byrne, William Ian et al.; 2018)

According to Hartsell (2017) Digital storytelling has many significance in teaching and learning process. It is a way to express ideas, beliefs and topics to listeners towards the use of technology and multimedia. In addition, digital stories promote storytellers acquire some integrated skills. Importantly, the storyteller learns to create stories using their voice and interpretation to be shared with others community. After that, self expression can be encouraged and developed by the creativity of digital stories.

Digital storytelling can also be used to enhance subject material, to share experiences or present new informations in a creative and inovative ways. It may be used as projects, homeworks or tasks. Teachers may start to ask students to make a stories by giving students easy projects first like create a short 30 second video report on a movie that they have watched regularly. Another assignment that would interest many of them would be to make a video on their own lives.

Digital storytelling requires various tools to create the story, including a computer. An internet connection, a camera or a video recording tool, a voice recorder or microphone, a music keyboard and a scanner can also be used. These tools can enhance and bring life to a digital story.

Digital storytelling can be simple or complex, depending on the creator's skill set. Professional storytellers are created with video software like inshot, iMovie, or Movie Maker, and other audio and image editing software. Professionals may even create their own music to go with the video. On the other hand, a digital storytelling can even be created by embedding a sound track into a power point presentation or using some simple online tools.

\section{Process of Digital storytelling}

The teachers need to facilitate their students to create the stories. As w e know that, the creation of digital stories is a good instructional strategy that has built the potential of students to transfer what they are learned to the stories. Digital stories are convenient as they are shared and documanted by using digital texts and tools. This admits teachers to document their work process and product of the students. Then, while permiting the students to show their work and their friends tasks. By creating digital stories means that transform the product of students works from traditional tasks to digital project. It allow them to explore thier capability in using technology. (Alonso et al.; 2013).

O’Byrne, William Ian et al. (2018) said that the teachers sould motivate their students to collaborate with their friends in making project. And also ask them to use several tools in making it. Then, encourage them to prepare their own stories and create the digital story. In 
digital stories, students have to express the content with others visualization like image, graphs, figure or animation.

There are various steps to digital storytelling:

The first obvious step is planning. Helping students plan their storyline helps them envision the story and implement it easily. The next step would be to collect images, videos or audio that they may need. They may need to record the audio in a quiet room, collect music tracks and shoot or collect videos that they are going to use. They may want to do some interviews to make the story even more interesting and interactive. They may also rehearse telling the story verbally and record it. You may experience a few technical difficulties when you start, and that's all part of the learning process.

\section{Presenting the Video}

Final step to the process of digital storytelling is to provide an opportunity for students to present their video in the classroom. Make sure you have a projector or similar equipment to allow the student to display their work to the whole class. Thus, digital storytelling is an exciting new way to get students to learn and present their learning.

\section{METHOD}

Cresswell (2009) states

"Experimental research design is to enable researcher to estimate the effect of an experimental treatment". Experimental research can be done in the laboratory, in a classroom and in a field. In this study, the experimental research did in the classroom with students as population.

An experimental usually involves two groups of subject, an experimental group and a control group. This study used experimental design in the form of two groups Pretest- Posttest design using quantitative approach. In experimental and control group the test did two times, pre-test and post-test without treatments.
Population is all of subject in such research. According to Arikunto (2013), population is the entire of research subject. If the researcher is going to conduct research of all elements in the research, the researcher is considered as population research. The study is also called population study. The population of this research is all students at fifth semester of English Students of FKIP UIR in academic year 2018/2019.

In the research, sample is taken from the population that has been decided. Arikunto (2013) states that sample is part of population that investigated. Sample research is the research that focuses on generalizing the result of sample research. The sampling technique used in this research is purposive sampling. The researcher choose $5 \mathrm{~B}$ as experimental class which consist of 26 students and 5C as control class which consist of 25 students.

\subsection{Instrument of the Research}

Research instrument is tool or facility that used by the researcher to collect the data in order the research can be easily collected and get better, complete, and systematic result. In this research, the instrument is documentation of speaking test. According to those statements, test document is the document shows the result of a test, which represented the students' measurement as a response of stimulus.

Table 1. Research materials/topics

\begin{tabular}{cclc}
\hline No & Meeting & \multicolumn{1}{c}{ Topic } & Activities \\
\hline 1 & $1^{\text {st }}$ & The student made & Pre- Test \\
& Meeting & a digital & for \\
& Monday, & storytelling with & experima \\
$13^{\text {th }}$ & theme: Describe & ntal class \\
& August & about place, & and \\
& person, and & control \\
& & things. & class
\end{tabular}




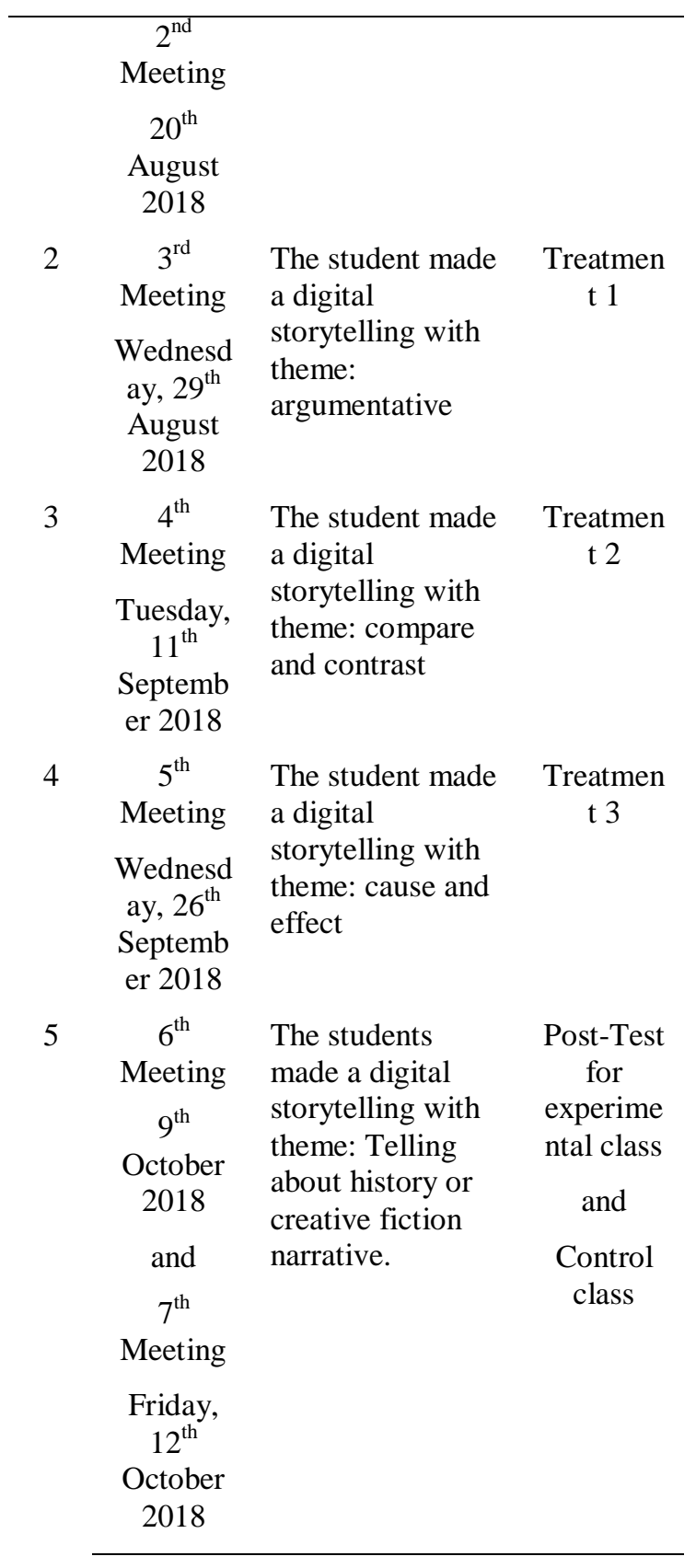

\subsection{Data Collection Techniques}

In this research, the researcher collected the data which need to suport this reasearch by applying the example of digital storytelling from storytelling websites to the students in the experimental and control group. It conducted for pre-test and post-test. The test used to know the students' speaking ability.

Firstly, Pre-test administered to the students before treatments. The purpose is to know the earely background ability of students in speaking. Secondly, the treatment done three meetings in experimental group. The last, Post-test administered after treatments in order to know the students speaking ability after having the teratment by using digital storytelling.

\subsection{Data Analysis Techniques}

In this research, the technique of analyzing the data divided into two ways: pre-test and post-test. The researcher focused on all aspect in student speaking ability, and the score calculated in all of it. The data analyzed by using some formulas and statistical package sciences (SPSS) program by 24 versions. The data collected and counted before and after the treatment test.

Table 2. The classification of students' scores

\begin{tabular}{cc}
\hline Level of Ability & Scores \\
\hline Good to Excellent & $80-100$ \\
Average to Good & $66-79$ \\
Poor to Average & $56-65$ \\
Poor & $40-55$ \\
\hline & Arikunto (2013)
\end{tabular}

\section{FINDINGS AND DISCUSSION}

The researcher assessed the students' speaking ability by using the scoring rubric which was consisting of five aspects on speaking ability. They were; Pronunciation, Vocabulary, Fluency, Grammar, and Comprehension.

The students' score in pre-test and pos-test for experimental and control classes could be explained in the following. 


\subsection{Experimental Class}

\section{Pre-test}

The researcher conducted the pretest for experimental class on Monday $13^{\text {th }}$ August 2018. Th result of the speaking test can be seen on the table below:

Table 3. Students' scores in pre-test for experiment class

\begin{tabular}{|c|c|c|c|c|c|}
\hline & & $\begin{array}{c}\text { Freq } \\
\text { uenc } \\
y\end{array}$ & Percent & $\begin{array}{c}\text { Valid } \\
\text { Perce } \\
\text { nt }\end{array}$ & $\begin{array}{l}\text { Cumulati } \\
\text { ve } \\
\text { Percent }\end{array}$ \\
\hline \multirow{6}{*}{$\begin{array}{l}\text { V } \\
\text { A } \\
\text { L } \\
\text { I } \\
\text { D }\end{array}$} & 65,00 & 7 & 26,9 & 26,9 & 26,9 \\
\hline & 70,00 & 6 & 23,1 & 23,1 & 50,0 \\
\hline & 75,00 & 8 & 30,8 & 30,8 & 80,8 \\
\hline & 80,00 & 2 & 7,7 & 7,7 & 88,5 \\
\hline & 85,00 & 3 & 11,5 & 11,5 & 100,0 \\
\hline & Total & 26 & 100,0 & 100,0 & \\
\hline
\end{tabular}

On the table 3, the reseacher presented the result of students' speaking ability particulary in the pre-test. From the total numbers of students were 26 students, reseacher found that the result of students speaking ability in pre-test was as follows: The highest score gained by the students was 85.00 which considered as good to excellent level. In contrary, the lowest score gained by the students was 65.00 that considered as poor to average level. The researcher also provided the students' mean score for pre-test was 72.69 .

Table 4. The students' clasification in pretest for experimental class

\begin{tabular}{ccccc}
\hline No & Categories & Score & $\begin{array}{c}\text { Frequ } \\
\text { ency }\end{array}$ & $\begin{array}{c}\text { Percent } \\
\text { age (\%) }\end{array}$ \\
\hline 1. & $\begin{array}{c}\text { Good to } \\
\text { Excellent } \\
\text { Average to } \\
\text { Good }\end{array}$ & $80-100$ & 15 & 19.23 \\
2. & $66-79$ & 14 & 53.85 \\
& $\begin{array}{c}\text { Poor to } \\
\text { Average } \\
\text { Poor } \\
\text { Total }\end{array}$ & $56-65$ & 7 & 26.92 \\
4. & $40-55$ & 0 & 0 \\
& & $\mathbf{2 6}$ & $\mathbf{1 0 0}$ \\
\hline
\end{tabular}

Referring to the table 4 illustrated above, the majority of the experimental class students in pre-test were classified into "Average to Good" category.

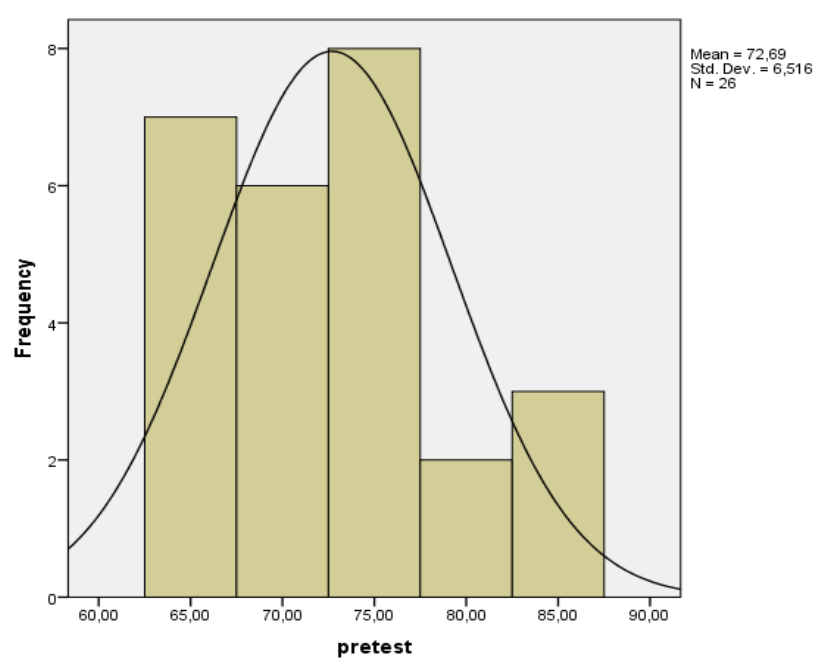

Figure 1. Normality of test in experimental class

Based on the bar chart in figure 1, it can be seen that the pattern of histogram was normal curve. Therefore, it can be concluded that the distribution of data in pre-test was normal. The researcher also provided the students' mean score for pretest that was 72.69 .

\section{Post-test}

The researcher conducted the posttest on Tuesday $9^{\text {th }}$ October 2018 in experimental class and the score presented below:

Table 5. Students' scores in post-test for experiment class

\begin{tabular}{|c|c|c|c|c|c|}
\hline & & $\begin{array}{c}\text { Frequ } \\
\text { ency }\end{array}$ & Percent & $\begin{array}{c}\text { Valid } \\
\text { Percen } \\
t\end{array}$ & $\begin{array}{c}\text { Cumulati } \\
\text { ve } \\
\text { Percent }\end{array}$ \\
\hline \multirow{6}{*}{$\begin{array}{l}\mathrm{V} \\
\mathrm{A} \\
\mathrm{L} \\
\mathrm{I} \\
\mathrm{D}\end{array}$} & 70,00 & 1 & 3,8 & 3,8 & 3,8 \\
\hline & 75,00 & 10 & 38,5 & 38,5 & 42,3 \\
\hline & 80,00 & 7 & 26,9 & 26,9 & 69,2 \\
\hline & 85,00 & 5 & 19,2 & 19,2 & 88,5 \\
\hline & 90,00 & 3 & 11,5 & 11,5 & 100,0 \\
\hline & Total & 26 & 100,0 & 100,0 & \\
\hline
\end{tabular}


From the data, the researcher found the result of the student speaking ability in the post test was as follow: The highest score gained by the students was 90.00 which considered as good to excellent level. On the other hand, the lowest score gained by the students was 70.00 that considered by average to good category. Then, the students' mean score for post-test was 79.81 .

Table 6. The students' clasification in

\begin{tabular}{|c|c|c|c|c|}
\hline No & Categories & Score & $\begin{array}{c}\text { Frequ } \\
\text { ency }\end{array}$ & $\begin{array}{l}\text { Percent } \\
\text { age (\%) }\end{array}$ \\
\hline 1. & $\begin{array}{l}\text { Good to } \\
\text { Excellent }\end{array}$ & $80-100$ & 15 & 57.69 \\
\hline 2. & $\begin{array}{l}\text { Average to } \\
\text { Good }\end{array}$ & $66-79$ & 11 & 42.31 \\
\hline 3. & $\begin{array}{l}\text { Poor to } \\
\text { Average }\end{array}$ & $56-65$ & 0 & 0 \\
\hline \multirow[t]{2}{*}{4.} & Poor & $40-55$ & 0 & 0 \\
\hline & Total & & 26 & 100 \\
\hline
\end{tabular}

Based on table 6 illustrated above, it can be seen that the majority of the experimental class students in pre-test were classified into "Good to excellent" category.

\subsection{Control Class}

\section{Pre-test}

The researcher conducted the pretest on Monday 20 ${ }^{\text {th }}$ August 2018 in Control class. Here, the researcher calculated the score after doing the pretest for control class.
Table 7. Students' scores in pre-test for control class

\begin{tabular}{|c|c|c|c|c|c|}
\hline & & $\begin{array}{c}\text { Freq } \\
\text { uen } \\
\text { cy }\end{array}$ & $\begin{array}{c}\text { Perce } \\
\text { nt }\end{array}$ & $\begin{array}{c}\text { Valid } \\
\text { Perce } \\
\text { nt }\end{array}$ & $\begin{array}{c}\text { Cumulative } \\
\text { Percent }\end{array}$ \\
\hline \multirow{7}{*}{$\begin{array}{l}\mathrm{V} \\
\mathrm{V} \\
\mathrm{L} \\
\mathrm{I} \\
\mathrm{D}\end{array}$} & 60,00 & 3 & 12,0 & 12,0 & 12,0 \\
\hline & 65,00 & 5 & 20,0 & 20,0 & 32,0 \\
\hline & 70,00 & 9 & 36,0 & 36,0 & 68,0 \\
\hline & 75,00 & 5 & 20,0 & 20,0 & 88,0 \\
\hline & 80,00 & 2 & 8,0 & 8,0 & 96,0 \\
\hline & 85,00 & 1 & 4,0 & 4,0 & 100,0 \\
\hline & Total & 25 & 100,0 & 100,0 & \\
\hline
\end{tabular}

On the table 7, the reseacher presented the result of student speaking ability particulary in the pre-test. From the total numbers of students were 25 students, reseacher found that the result of students speaking ability in pre-test was as follows: The highest score gained by the students was 85.00 which considered as good to excellent level. Otherwise, the lowest score gained by the students was 60.00 that considered as poor to average level. The researcher also provided the students' mean score for pre-test was 70.20 .

Table 8. The students' clasification in pretest for control class

\begin{tabular}{ccccc}
\hline No & Categories & Score & $\begin{array}{c}\text { Freq } \\
\text { uenc } \\
\mathbf{y}\end{array}$ & $\begin{array}{c}\text { Percent } \\
\text { age (\%) }\end{array}$ \\
\hline 1. & $\begin{array}{c}\text { Good to } \\
\text { Excellent }\end{array}$ & $80-100$ & 3 & 12.00 \\
2. & $\begin{array}{c}\text { Average to } \\
\text { Good }\end{array}$ & $66-79$ & 14 & 56.00 \\
& $\begin{array}{c}\text { Poor to } \\
\text { Average }\end{array}$ & $56-65$ & 8 & 32.00 \\
4. & Poor & $40-55$ & 0 & 0 \\
& Total & & $\mathbf{2 6}$ & $\mathbf{1 0 0}$ \\
\hline
\end{tabular}

Referring to the table 8 illustrated above, it can be seen that there were 8 
students got score (56-65) and categorized as "Poor to Average, then 14 students got score (66-79) and categorized as "Average to Good", and there were 3 students got score (80-100) which were categorized as "Good to Excellent", thus, the majority of the experimental class students' in pre-test were classified into "Average to Good" category.

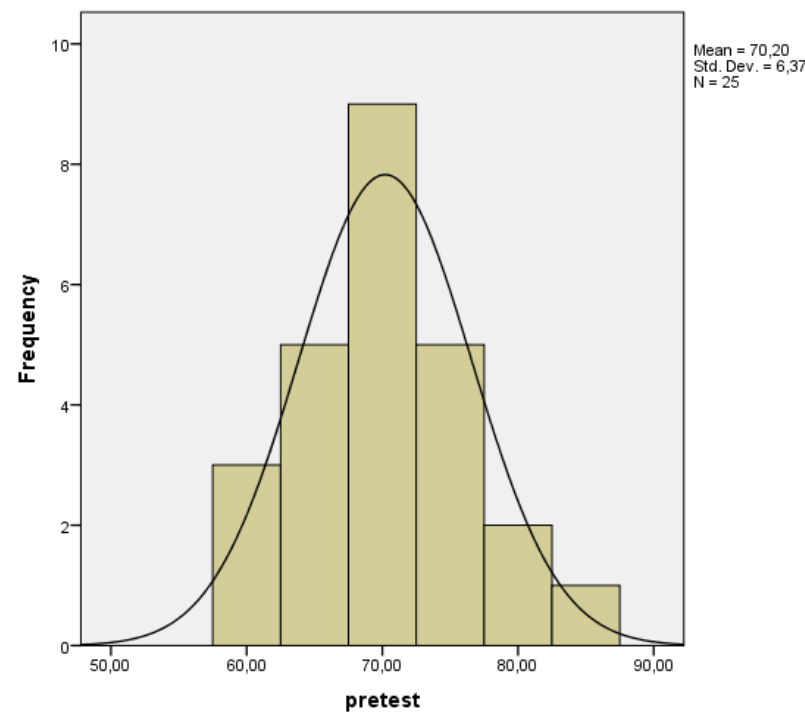

Figure 2. Normality of test in control class

Based on the histogram in figure 2 , it can be seen that the pattern of histogram was normal curve. Therefore, it can be concluded that the distribution of data in pre-test was normal. The researcher also provided the students' mean score for pre-test that was 70.20.

\section{Post-test}

The researcher conducted the posttest on Friday, $12^{\text {th }}$ October 2018 in control class and the scores that have been calculated as follow:
Table 9. Students' scores in post-test for control class

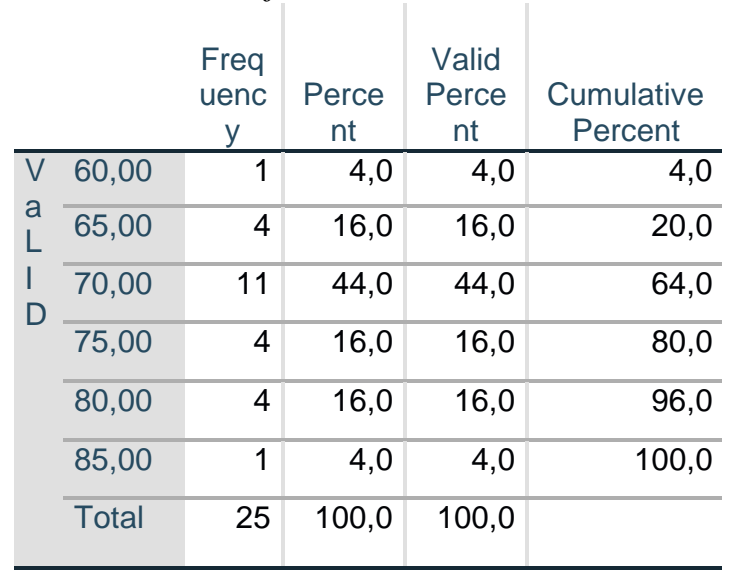

From table 9, it can be seen that the result of students' speaking skill particularly in the post test. The highest score gained by the students was 85.00 which considered as average to good level. On the other hand, the lowest score gained by the students was 60.00 that considered as poor to average level.

Table 10. The students' clasification in post-test for control class

\begin{tabular}{|c|c|c|c|c|}
\hline No & Categories & Score & $\begin{array}{c}\text { Freq } \\
\text { uency }\end{array}$ & $\begin{array}{c}\text { Percen } \\
\text { tage }\end{array}$ \\
\hline 1. & $\begin{array}{l}\text { Good to } \\
\text { Excellent }\end{array}$ & $80-100$ & 5 & 20.00 \\
\hline 2. & $\begin{array}{l}\text { Average to } \\
\text { Good }\end{array}$ & $66-79$ & 15 & 60.00 \\
\hline 3. & $\begin{array}{l}\text { Poor to } \\
\text { Average }\end{array}$ & $56-65$ & 5 & 20.00 \\
\hline 4. & $\begin{array}{l}\text { Poor } \\
\text { Total } \\
\end{array}$ & $40-55$ & $\begin{array}{c}0 \\
26 \\
\end{array}$ & $\begin{array}{c}0 \\
100 \\
\end{array}$ \\
\hline
\end{tabular}

Referring to the table 10 illustrated, it can be seen that the majority of the control class students in pre-test were classified into "Average to Good" category.

\subsection{Data Interpretation}

Based on analyzed of pre-test and post-test from the calculation above, it can be seen the differences of student's speaking score in pre-test and post-test. It means there was significant improvement 
of students' speaking ability after being treatment by using Digital Storytelling. The progress explained that students' speaking ability after using Digital Storytelling can develop the student speaking ability.

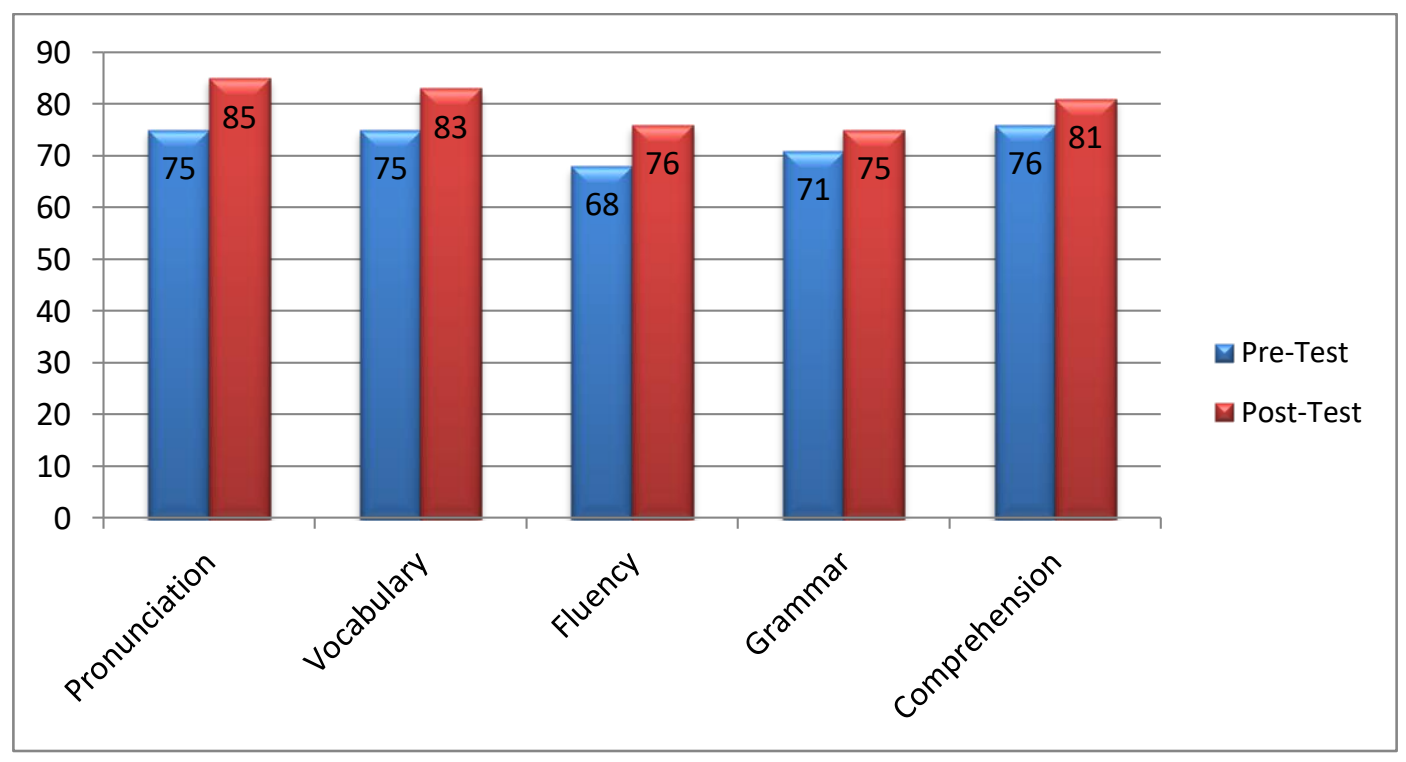

Figure 3. Speaking scores in experimental class (pre-test and post-test)

From the figure, it could be seen the mean score of students' scores in every aspects of speaking, there were pronunciation, vocabulary, fluency, grammar, and comprehension. Based on the bar chart, students' pronunciation was significantly increased about 10 points from mean score 75 points to 85 points. On the other hand, grammar was the lowest aspect which increased about only
4 points (mean score $71-75$ ). It means that grammar should be focused on the next lesson. Then, for other aspects like vocabulary, Comprehension, and Fluency were increased around 5 points until 8 points. Generally, we can see that the mean scores of the students' increased in every aspects of speaking ability after implemented the digital storytelling.

Table 11. Descriptive statistics

\begin{tabular}{lr|r|r|r|r} 
& N & Minimum & Maximum & Mean & Std. Deviation \\
\hline Pre_test_exp_class & 26 & 65,00 & 85,00 & 72,6923 & 6,51625 \\
\hline Post_test_exp_class & 26 & 70,00 & 90,00 & 79,8077 & 5,56431 \\
\hline Valid N (listwise) & 26 & & & & \\
\hline
\end{tabular}

Based on table 11, it can be seen that the comparison between the mean score of pre-test and post test in experimetal class. In the pre test, the mean score was 72.69 while in post test the mean score was 79.81. Following that, the minimum scores were 65,00 for pre test and 70.00 for post test. On the other hand, the maximum scores were 85.00 for pre test and 90 for post test. 


\subsection{Hypothesis Testing}

In order to find out whether the null hypothesis or the alternative hypothesis is accepted, firstly we need to find out the ttest. The researcher calculated of the t-test using paired samples test as follow:

Table 12. Paired samples statistics

\begin{tabular}{|c|c|c|c|}
\hline Mean & $\mathrm{N}$ & $\begin{array}{c}\text { Std. } \\
\text { Deviation }\end{array}$ & $\begin{array}{l}\text { Std. } \\
\text { Error } \\
\text { Mean }\end{array}$ \\
\hline
\end{tabular}

\begin{tabular}{l|l|l|l|l|l}
\hline Pair & pretest & 72,692 & 26 & 6,51625 & 1,2779 \\
\cline { 2 - 6 } 1 & posttest & 79,807 & 26 & 5,56431 & 1,0912 \\
\hline
\end{tabular}

Based on the table 11, it can be seen that the mean score of pre test and post test for experimental class. The result of mean score was significantly increased 7.12 points with the total of students was 26. While the standard deviation of pre test was 6.51 and post test 5.56.

Table 13. Paired samples test

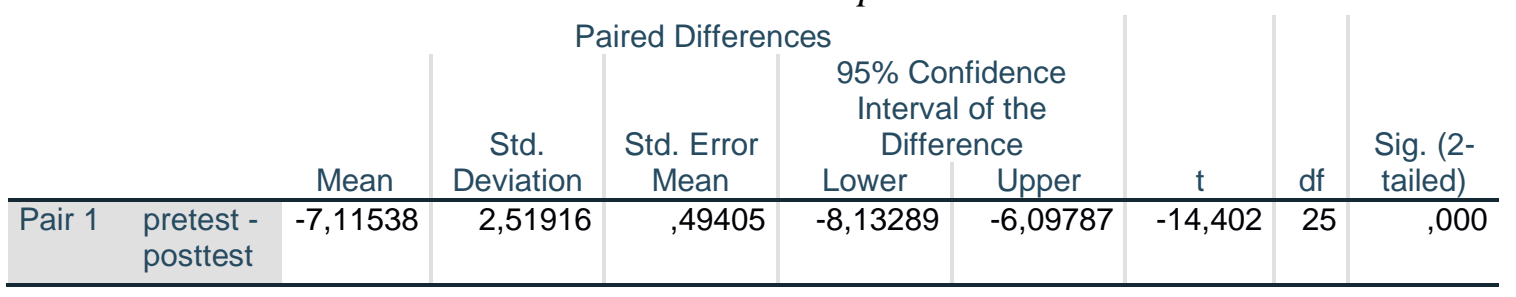

From the table, it can be seen that the increase of mean score in experimental group was 7.12. Then, the confidence interval of difference used was $95 \%$. It was used because the value of alpha (p) was 0.05 which means that the deviation of normal distribution was $5 \%$. First, the null hypothesis (H0) was rejected if $\mathrm{t}$-obs was higher than $\mathrm{t}$-table ( $\mathrm{t}$ obs>t-table). Second, the null hypothesis was rejected if the probability was less than 0.05 (sig. 2 tailed<0.05). In the table above, we could see that the value of t-obs was higher than that of t-table $(14,402>2.05954)$. In addition, the value of probability significance (2-tailed) column shows $0.000<0.05$. Based on the analysis, those two criteria of rejection are fulfilled. Therefore, it can be concluded that the null hypothesis was rejected and alternative hyphotesis was accepted. Consequently, it could be seen that there was a significant mean difference between the experimental and the control groups. In summary, there was a significant effect of Digital Storytelling toward students' speaking ability at English Study Program FKIP UIR.

\section{CONCLUSION}

Based on the result of this study, it could be concluded that Digital Storytelling can be used as a media for students in order to develop their speaking ability especially in term of pronunciation, vocabulary, fluency, grammar and comprehension. It supported by showing the result of pre-test and posttest in experiment class. In addition, it showed that the result of pre-test and posttest indicated that there is a significant increase of the students speaking performance. Following that, this study also provides meaningful information for both language teachers and students which is necessary to use media in the process of learning English.

This study suggests the implementation of Digital Storytelling for higher education in speaking classroom. Then, this media gives concrete and useful input related to the native or nonnative speakers performance in using English. The result of this study also finds that the implementation of Digital Storytelling can develop students' motivation in speaking and also challenging. However, it can attract the 
students' attention and influence the students to be actively involved in doing the activities. Thus, further research involving greater respondents is required to find better understanding on the implementation of Digital Storytelling in speaking classroom. Further, it is suggested for future researchers to conduct a further research dealing with the implementation of Digital Storytelling on the other English language skills.

The researcher would like to give some suggestions for the teacher, students and for the next researcher. First, the teacher should make active media in teaching English in classroom, by using some application or technology. The student can create digital storytelling and enjoy for the new media in learning Process. Second, the teacher should choose or create the appropriate in order to the students easier to understand the material. The last, in applied this media, the teacher should explain clear instruction to the students.

In this time, the researcher found that the students were difficult to speak in classroom. Therefore, this media can make the students active, motivate to speak in front of the class. Don't be shy to practice, because practice makes you're speaking became perfect.

To the next researcher can find the new media which could help the students to be active in learning process, and make them interested with English class. Next, the researcher expected that the existence of this study could provide and give some contributions for those who conduct out the similar discussion.

\section{BIBLIOGRAPHY}

Alonso, I., Molina, S., and Requejo, M. D. P. (2013). Multimodal digital storytelling: integrating information, emotion and social cognition. Rev. Cogn. Linguist. 11,
369-387.

doi:

10.1075/rcl.11.2.10alo

Amiri, E. 2012. A Study of the Application of Digital Technologies in Teaching and Learning English Language and Literature, International Journal of Scientific and Technology Research, 1 (5), 103-107.

Arikunto. S. 2013. Prosedur Penelitian: Suatu Pendekatan Praktik. Jakarta: Rineka Cipta.

Ashaver, D., Igyuve, S. M. 2013. The Use of Audio-Visual Materials in the Teaching and Learning Processes in Colleges of Education in Benne State. Negeria, IOSR Journal of Research and Method in Education, 1 (6), 44-55.

Cherry, W. R. Jr. (2017). Our place in the universe: the importance of story and storytelling in the classroom. Knowledge Quest 46, $50-55$.

Cresswell, John. W. 2009. Reseach Design. Qualitative, Quantitative, and Mix Methods Approches. 3rd Ed. New Jersey: Pearson Education.

Clarke, R. \& Adam, A. 2011. Digital storytelling in Australia: Academic perspectives and reflections. Arts and Humanities in Higher Education, 11(1-2), 157176.

Dreon, O., Kerper, R. M. \&Landis, J. (2011). Digital Storytelling: A tool for teaching and learning in the Youtube Generation. Middle School Journey, 5 (42), 4-9. 
Hartsell, Taralynn (2017). Digital Storytelling: An Alternative Way of Expressing Oneself. International Journal of Information and Communication Technology Education (IJICTE)13(1).

Karakoyun, F. (2014). Examining the views of elementary school students and preservice teachers about digital storytelling activities in online environment. Ph.D Thesis. Anadolu University, Institute of Educational Science, Eskişehir, Turkey.

Khorashadyzadeh, A. (2014). Why to use short stories in speaking classes? International Journal of Foreign Language Teaching in the Islamic World, 2(1), 9-15.

Madhavaiah, G., Nagaraju, Ch., Peter,S. (2013). Importance of Technology in Teaching and Learning English Language, International Journal of Scientific Research and Reviews. 2 (3), 146-154.

Maggioli, G. D. (2009). Teaching English with Technology. Pearson: Longman.

O’Byrne, William Ian., Houser, Katherine., and Stone, Ryan (2018). Digital Storytelling in Early Childhood: Student Illustrations Shaping Social Interactions. College of Charleston, Charleston, SC, United States. Human Media Interaction.

Wang, S. \& Zhan, H. (2010). Enhancing teaching and learning with digital storytelling. International Journal of Information and Communication Technology
Education

6 (2), 76-87.

.

